\title{
Reacción álcali sílice en el hormigón debido al mortero adherido del árido reciclado
}

\author{
Alkali silica reaction in concrete induced by mortar adhered \\ to recycled aggregate
}

\author{
M. Etxeberria (*), E. Vázquez ${ }^{(*)}$
}

Recepción/Received: 8-II-08

Aceptación/Accepted: 7-VII-08

Publicado online/Online publishing: 23-II-10

\section{RESUMEN}

La durabilidad del hormigón fabricado con árido reciclado es necesario determinarla antes de su utilización como material de construcción. En este artículo se analiza la reacción álcali-sílice manifestada en el hormigón fabricado con árido reciclado procedente de hormigón (compuesto de árido original calizo y mortero adherido de arena sílice reactiva), y cemento de alto contenido en álcalis. Debido al proceso de fabricación del hormigón y la alta capacidad de absorción del árido reciclado se produce una acumulación del cemento en la Interfase (ITZ). Debido al contacto directo de los álcalis del cemento con la arena sílice reactiva se produce una reacción álcali sílice a los 6 meses de edad del hormigón. Se realiza un análisis mediante microscopio electrónico de barrido ambiental (ESEM) y sistema analítico de EDX. Se determina que las propiedades mecánicas del hormigón reciclado a 6 meses son similares a las obtenidas a los 28 días de curado.

Palabras clave: hormigón con árido reciclado, reacción álcali árido, zona interfacial, SEM, EDX.

\begin{abstract}
SUMMARY
The durability of recycled concrete must be determined before this material can be used in construction. In this paper the alkali-silica reaction in recycled concrete is analyzed. The recycled concrete is made with recycled aggregates, composed by original limestone aggregates and adhered mortar with reactive silica sand, and high alkali content cement. Due to the manufacturing process used for concrete production and the high water absorption capacity of recycled aggregates, cement accumulation happens in the interface (ITZ). The concentration of alkalis on the surface of recycled aggregates- ITZ and the presence of reactive sand in the mortar adhering to the recycled aggregate induce an alkali-silica reaction in 6-month concrete. The existence of this reaction is confirmed by environmental scanning electron microscopy (ESEM) and EDX analysis. The mechanical properties of 6-month recycled concrete were similar to those values at 28-days of curing.
\end{abstract}

Keywords: recycled concrete, alkali-aggregate reaction, interfacial transition zone, SEM, EDX.

(*) Universidad Politécnica de Catalunya (UPC) (Barcelona, España).

Persona de contacto/Corresponding author: miren.etxeberria@upc.edu 


\section{INTRODUCCIÓN}

La abundante cantidad de residuos de hormigón que se generan de las demoliciones de estructuras hace necesaria su reutilización como material de construcción. Hoy en día, la durabilidad de los hormigones fabricados con áridos reciclados, es desconocida y se puede decir que todavía no se ha medido con suficiente precisión. El hormigón fabricado con áridos reciclados ha de ser tan durable como un hormigón convencional. Los problemas de durabilidad que podrían presentar los hormigones de árido reciclado, pueden ser la consecuencia del desconocimiento del origen del árido reciclado utilizado en su fabricación.

En España, la arena triturada no fue utilizada como árido fino para la fabricación de hormigón hasta los años 80 . En consecuencia, el hormigón de demolición procedente de estructuras construidas antes de los 80 requiere una gran atención debido a que fueron fabricados con arena de río, en la cual, la sílice, probablemente reactiva, podría ser la principal componente (1).

En este artículo, el hormigón a estudiar se fabricó con árido reciclado procedente de la trituración del residuo de hormigón fabricado con arena de río de composición silícea y se utilizó el cemento Portland de alta resistencia y rápido endurecimiento con alto contenido en álcalis. En este trabajo se describe el óptimo proceso de fabricación del hormigón, el cual produce una efectiva zona de transición (ITZ) (debido a la acumulación del cemento en la superficie del árido reciclado y su alta capacidad de absorción de agua). Una efectiva ITZ mejora las propiedades mecánicas de los hormigones fabricados con áridos reciclados $(2,3)$. Sin embargo, la acumulación del cemento en la superficie de los áridos, y básicamente en la superficie del mortero adherido, produce una gran concentración de álcalis en la ITZ. El contacto de estos álcalis con los áridos silicios reactivos podría influir en una rápida reacción álcali-sílice y esto es lo que se analiza en este artículo.

\section{ESTUDIO EXPERIMENTAL}

El hormigón con árido reciclado estudiado en este artículo, se fabricó utilizando $100 \%$ de árido grueso reciclado y arena caliza triturada.

El árido reciclado utilizado en la fabricación del hormigón procedía de una planta de reciclaje, y su origen y edad eran desconocidos. La obtención de las muestras y todas las propiedades de los áridos se determinaron de acuerdo con las Normas EN.

\section{INTRODUCTION}

The construction industry must find ways to re-use the concrete present in the huge amounts of demolition waste generated yearly. At this time, however, the durability of recycled concrete is unknown for want of accurate measuring procedures. Concrete manufactured with recycled aggregate must be no less durable than conventional concrete. The durability problems posed by recycled concrete may be attributed in part to a lack of information about the origin of the recycled aggregate used to make it.

In Spain, crushed sand was not used as a fine aggregate in concrete manufacture until the nineteen eighties. Consequently, demolition concrete from structures built prior to that decade must be examined in detail before re-use, for it contains rolled sand whose main component may have been (very likely reactive) silica (1).

The concrete analyzed in the present study was made by mixing recycled aggregate prepared by crushing waste concrete containing siliceous rolled sand with highstrength, rapid-hardening Portland cement that had a high alkali content. The paper describes the optimal process for concrete manufacture, which generates an effective interfacial transition zone (ITZ), due to the accumulation of the cement on the surface of the recycled aggregate and its high water sorptivity. An effective ITZ improves the mechanical properties of concretes manufactured with recycled aggregate $(2,3)$. The accumulation of cement on the aggregate surface, and essentially on the surface of the adhered mortar, however, leads to a high concentration of alkalis in the ITZ. The contact between these alkalis and the reactive siliceous aggregate may favour the early appearance of the alkali-silica reaction, which is the object of this study.

\section{EXPERIMENTAL STUDY}

The recycled concrete studied in this article was manufactured with $100 \%$ recycled coarse aggregate and crushed limestone sand.

The origin of the recycled aggregate, which was furnished by a recycle plant, was unknown. Samples were obtained and the properties of the aggregate determined in accordance with European (EN) standards. 


\subsection{Propiedades de los materiales}

\subsubsection{Composición del árido reciclado}

El árido reciclado procedente de hormigón está compuesto de árido natural más mortero adherido, el cual consiste en pasta de cemento y arena original. Para la realización de un análisis exhaustivo de los áridos reciclados, se analizó cada una de los materiales que lo componen: el árido grueso reciclado, el árido grueso original y el mortero adherido del árido grueso reciclado. Tal y como se muestra en la Tabla 1, la composición principal del árido reciclado era el $\mathrm{SiO}_{2}$ en un 53\%. La composición del árido grueso original fue analizado y determinado visualmente y se definió como: $74 \%$ calizo, $10 \%$ granítico, $10,6 \%$ metamórfico y 5,2\% cuarzo. Teniendo en cuenta la composición del árido reciclado y del árido grueso original, se determinó que el silicio era el componente principal del árido fino, arena, presente en el mortero adherido. La composición de la arena del mortero adherido fue determinada utilizando el microscopio electrónico de barrido ambiental (ESEM) y sistema de análisis EDX. La arena fue clasificada como cuarzo (ver Figura 1). La composición fue determinada analizando una amplia cantidad de muestras.

\subsection{Materials: properties}

\subsubsection{Recycled aggregate composition}

The aggregate recycled from concrete consisted of natural aggregate plus adhered mortar, in turn containing cement paste and the original sand. Each of these constituents was analyzed: the recycled coarse aggregate, the original coarse aggregate and the mortar adhered to the recycled coarse aggregate. As Table 1 shows, at 53\%, $\mathrm{SiO}_{2}$ constituted the main component of the recycled aggregate. The composition of the original aggregate was analyzed and determined visually as follows: $74 \%$ limestone, $10 \%$ granite, $10.6 \%$ metamorphic rock and $5.2 \%$ quartz. Given the differences in the composition of the recycled and the original coarse aggregate, the silicon present in the former was determined to have been the main component of the fine aggregate (sand) used to make the adhered mortar. Environmental scanning electron microscopy (ESEM) and EDX analysis showed that the chief mineral component of the sand was quartz (see Figure 1). This finding was based on the analysis of a large number of samples.

Tabla 1 / Table 1

Composición principal de los áridos reciclados.

Physical properties of the aggregate.

\begin{tabular}{|c|c|c|c|c|c|c|c|c|c|c|}
\hline \multicolumn{11}{|c|}{ Análisis químico / Chemical analysis } \\
\hline Árido reciclado / Recycled aggregate & $\mathrm{Fe}_{2} \mathrm{O}_{3}$ & Mno & $\mathrm{TiO}_{2}$ & $\mathrm{CaO}$ & $\mathrm{K}_{2} \mathrm{O}$ & $\mathbf{P}_{2} \mathbf{O}_{5}$ & $\mathrm{SiO}_{2}$ & $\mathrm{Al}_{2} \mathrm{O}_{3}$ & MgO & $\mathrm{Na}_{2} \mathrm{O}$ \\
\hline$\%$ & 2.51 & 0.06 & 0.29 & 27.92 & 1.47 & 0.10 & 52.95 & 6.97 & 4.33 & $<$ Limit \\
\hline
\end{tabular}

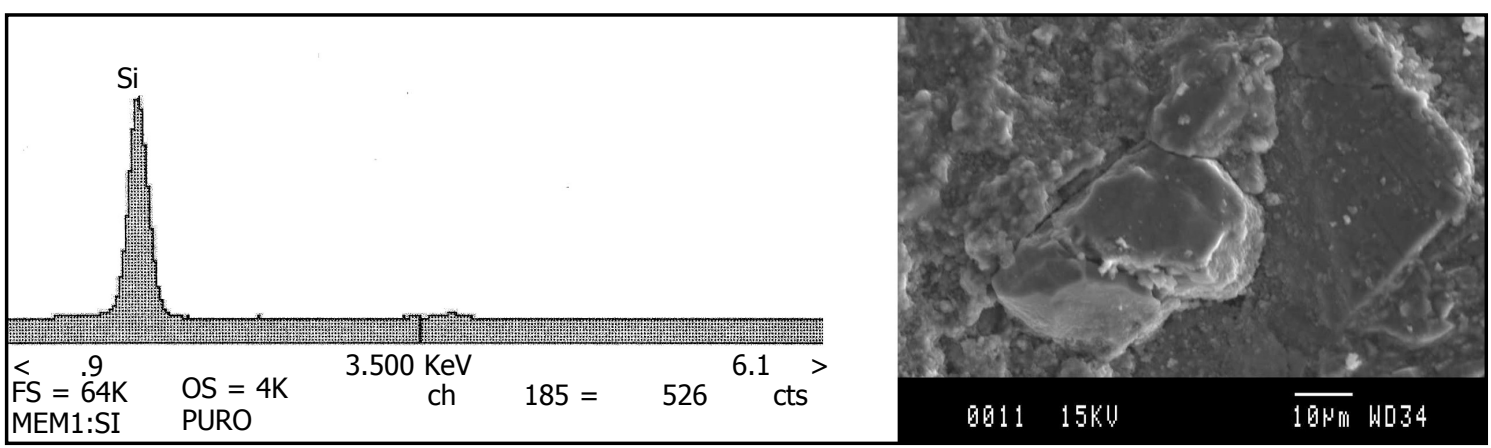

Figura 1. Análisis mediante EDX (a) y SEM (b) diferentes puntos de los áridos. El cuarzo fue detectado.

Figure 1. EDX (a) and SEM (b) analysis of different point on the aggregate, which proved to contain primarily quartz.

\subsubsection{Propiedades físicas del árido reciclado y natural}

El mortero adherido presente en los áridos reciclados, tiene un doble efecto en su propiedad: a) causa una reducción de la densidad, b) causa un aumento de la capacidad de absorción de agua con respecto a la misma propiedad del árido convencional. Las propiedades físicas fueron determinadas de acuerdo a las especificaciones EN (ver Tabla 2).

\subsubsection{Physical properties of the recycled and natural aggregate}

The adhered mortar had a dual effect on the properties of the recycled aggregate: a) it reduced density and b) increased water sorptivity. The physical properties studied were determined as specified in European (EN) standards (see Table 2). 
Tabla 2 / Table 2

Propiedades físicas de los áridos.

Physical properties of the aggregate.

\begin{tabular}{|c|c|c|c|c|}
\hline \multirow{2}{*}{$\begin{array}{c}\text { Test } \\
\text { EN } \\
1097-6: 2000\end{array}$} & \multicolumn{2}{|c|}{ Árido convencional / Conventional aggregate } & \multicolumn{2}{|c|}{ Árido reciclado / Recycled aggregate } \\
\hline & $\begin{array}{l}\text { Arena caliza / Limestone sand } \\
\qquad(\mathbf{0 - 4 )}\end{array}$ & $\begin{array}{c}\text { Grueso / Coarse } \\
(\mathbf{4 / 1 0 )}\end{array}$ & $\begin{array}{c}\text { Grueso / Coarse } \\
(\mathbf{1 0 / 1 6 )}\end{array}$ & $\begin{array}{c}\text { Grueso / Coarse } \\
(16 / 25)\end{array}$ \\
\hline \multicolumn{5}{|c|}{ Densidad / Density $\left(\mathrm{kg} / \mathrm{m}^{3}\right)$} \\
\hline$d_{r d}$ & 2.495 & 2.306 & 2.327 & 2.361 \\
\hline $\mathrm{d}_{\mathrm{ssd}}$ & 2.560 & 2.415 & 2.427 & 2.452 \\
\hline $\mathrm{d}_{\mathrm{A}}$ & 2.669 & 2.589 & 2.586 & 2.598 \\
\hline \multicolumn{5}{|c|}{ Porosidad / Porosity (\%) } \\
\hline$P$ & 6.53 & 10.938 & 9.994 & 9.134 \\
\hline \multicolumn{5}{|c|}{ Absorción / Absorption (\%) } \\
\hline$A_{p}$ & 2.619 & 4.743 & 4.296 & 4.296 \\
\hline
\end{tabular}

\subsubsection{Cemento}

En la fabricación del hormigón se utilizó el Cemento Portland de alta resistencia y rápido endurecimiento CEM I 52.5R (4). El análisis químico y los constituyentes del cemento se ilustran en la Tabla 3 y Tabla 4, respectivamente.

\subsubsection{Cement}

High-strength, rapid hardening Portland cement (CEM I 52.5R) was used to manufacture the concrete (4). The chemical analysis of the cement is given in Table 3 and its constituents listed in Table 4.

Tabla 3 / Table 3

Composición química del cemento.

Chemical composition of the cement.

\begin{tabular}{|c|c|c|c|c|c|c|c|c|}
\hline \multicolumn{1}{|c|}{ Análisis químico / Chemical analysis } \\
\hline Composición / Composition & $\mathbf{S i O}_{\mathbf{2}}$ & $\mathbf{A l}_{\mathbf{2}} \mathbf{O}_{\mathbf{3}}$ & $\mathbf{F e}_{\mathbf{2}} \mathbf{O}_{\mathbf{3}}$ & $\mathbf{C a O}$ & $\mathbf{M g O}$ & $\mathbf{S O}_{\mathbf{3}}$ & $\mathbf{N a}_{\mathbf{2}} \mathbf{O}$ & $\mathbf{K}_{\mathbf{2}} \mathbf{O}$ \\
\hline$\%$ & 20.19 & 5.25 & 3.68 & 62.81 & 1.80 & 3.02 & 0.15 & 0.86 \\
\hline
\end{tabular}

Tabla 4 / Table 4

Constituyente del cemento.

Cement constituents.

\begin{tabular}{|c|c|c|c|c|c|}
\hline \multicolumn{7}{|c|}{ Constituyente / Constituent } \\
\hline Composición / Composition & $\mathbf{C}_{\mathbf{3}} \mathbf{S}$ & $\mathbf{C}_{\mathbf{2}} \mathbf{S}$ & $\mathbf{C}_{\mathbf{3}} \mathbf{A}$ & $\mathbf{C}_{\mathbf{4}} \mathbf{A F}$ & $\mathbf{N a}_{\mathbf{2}} \mathbf{O}$ equiv. \\
\hline$\%$ & 53.11 & 17.82 & 7.69 & 11.20 & 0.71 \\
\hline
\end{tabular}

\subsection{Metodología}

\subsubsection{Reactividad del árido reciclado}

La reactividad del árido grueso reciclado con respecto al álcali fue determinada debido a la alta cantidad de la sílice encontrada en su composición. El ensayo fue llevado a cabo de acuerdo a la norma ASTM C1260 (5). El árido grueso reciclado y el mortero adherido presente en el árido reciclado se ensayaron por separado para obtener la reactividad de cada uno de ellos.

\subsubsection{Fabricación de hormigón con árido reciclado}

La fabricación del hormigón se llevó a cabo en una amasadora automática. Se determinaron las propiedades mecánicas del hormigón a 28 días y 6 meses de curado. Después de 6 meses de curado el hormigón de árido reciclado, en condición de saturación ( $100 \%$ de humedad),

\subsection{Methodology}

\subsubsection{Recycled aggregate reactivity}

In light of its high silica content, the recycled coarse aggregate was tested for its reactivity with alkalis as specified in Standard ASTM C1260 (5). The recycled coarse aggregate and the mortar adhered to it were tested separately to obtain the reactivity of each.

\subsubsection{Concrete manufacture with recycled aggregate}

The concrete was prepared in an automatic mixer. The mechanical properties of 28-day and 6-month recycled concrete were found. The recycled concrete was cured at $100 \%$ relative humidity for 6 months and then heated at $40{ }^{\circ} \mathrm{C}$. These environmental conditions accelerated the 
fue sometido a $40^{\circ} \mathrm{C}$. Las nuevas condiciones ambientales causaron una aceleración en la reacción química, y surgieron unas aureolas alrededor del mortero adherido del árido reciclado. Se realizó un análisis microscópico mediante microscopio óptico y ESEM para describir este fenómeno.

\section{Metodología de mezcla y dosificación del hormigón con árido reciclado}

Para la fabricación del hormigón se utilizó una mezcladora automática de 250 I de capacidad. En la primera fase del mezclado los áridos finos y gruesos fueron mezclados durante 30 segundos. La segunda fase consistió en añadir cemento y mezclar todos los materiales durante 30 segundos. En la tercera fase se añadió agua a la mezcla de cemento y áridos y se mezcló todo durante 1 minuto. La cuarta y última fase consistió en añadir manualmente el superplastificante y mezclar el material durante 1 minuto antes de parar la máquina.

Los áridos reciclados tienen una alta capacidad de absorción y se deberían de utilizar húmedos para reducir su capacidad de absorción, antes de su utilización en la fabricación del hormigón (3, 6-7). No es recomendable utilizar los áridos reciclados en condición de saturación, ya que la saturación del árido reciclado produce una ineficiente ITZ entre el árido reciclado saturado y la nueva pasta de cemento debido a la acumulación del agua en la superficie. En este trabajo la fabricación del hormigón se realizó con áridos reciclados húmedos (8). Los áridos se utilizaron con un $80 \%$ de humedad.

En el hormigón estudiado, la trabajabilidad del hormigón fresco fue de 8-10 cm de acuerdo con el ensayo de consistencia (9).

La dosificación del hormigón con árido reciclado se ilustra en la Tabla 5. Los áridos, cemento y agua son dados en peso $(\mathrm{kg})$ para producir $1 \mathrm{~m}^{3}$ de hormigón y el aditivo se expresa en \% respecto al peso de cemento y la relación a/c se considera como la relación a/c efectiva. chemical reaction, which led to the formation of halos around the mortar adhered to the recycled aggregate. These halos were studied under optical and environmental scanning electron microscopes.

\section{Recycled concrete mixing and dosage}

The concrete was prepared in a 250-I automatic mixer in four continuous stages. In the first, the fine and coarse aggregate were mixed for 30 seconds. The cement was added in the second stage and mixed with the other materials for another 30 seconds. In the third stage water was added to the cement and aggregate and all the components were mixed for 1 minute. $A$ superplasticizer was added manually in the fourth and final stage and the five components were mixed for another minute.

The recycled aggregate had to be moistened prior to concrete manufacture to reduce its high sorptivity (3, 67). The use of soaked recycled aggregate is not recommendable because the water accumulated on its surface renders the ITZ between the aggregate and the new cement paste inefficient. The concrete prepared for this study was made with (80\%) moistened recycled aggregate (8).

The fresh concrete was batched to have an $8-10-\mathrm{cm}$ slump (9) to ensure workability.

The recycled concrete dosage is given in Table 5. The aggregate, cement and water are shown by weight $(\mathrm{kg})$ per $\mathrm{m}^{3}$ of concrete, the admixture is expressed in per cent by weight of the cement and the $\mathrm{w} / \mathrm{c}$ ratio given was regarded to be the effective ratio.

Tabla 5 / Table 5

Dosificación del hormigón fabricado con $100 \%$ de árido grueso reciclado (RAC). La relación a/c es la relación efectiva de la pasta. Áridos, cemento y agua se dan en masa $(\mathrm{kg})$.

Mix proportion of concrete made with $100 \%$ recycled coarse aggregates (RCA). The $w / c$ ratio is the effective value in the paste. Aggregates, cement and water are given in mass $(\mathrm{kg})$.

\begin{tabular}{|c|c|c|c|c|c|c|c|c|}
\hline & $\begin{array}{c}\text { Arena caliza / } \\
\text { Limestone sand } \\
\mathbf{( 0 / 4 )}\end{array}$ & $\begin{array}{c}\text { Árido reciclado / } \\
\text { Rec.aggregate } \\
\mathbf{( 4 / 1 0 )}\end{array}$ & $\begin{array}{c}\text { Árido reciclado / } \\
\text { Rec.aggregate } \\
\mathbf{( 1 0 / 1 6 )}\end{array}$ & $\begin{array}{c}\text { Árido reciclado / } \\
\text { Rec.aggregate } \\
\mathbf{( 1 6 / 2 5 )}\end{array}$ & Cem. & $\begin{array}{c}\text { Superplast. / } \\
\text { Superplastiz. } \\
\text { \% }\end{array}$ & $\begin{array}{c}\text { Agua / } \\
\text { Water }\end{array}$ & $\begin{array}{c}\text { a/c (w/c) } \\
\text { efec. / effec. }\end{array}$ \\
\hline RAC & 683.2 & 425.8 & 306.4 & 391.2 & 325 & 1.90 & 179 & 0.50 \\
\hline
\end{tabular}

Las aureolas aparecieron alrededor del mortero adherido del árido reciclado (ver Figura 2) cuando el hormigón con áridos reciclados fue sometido a condición de temperatura alta $\left(40^{\circ} \mathrm{C}\right)$ y manteniendo la condición de $100 \%$ de humedad.
The halos appeared around the mortar adhered to the recycled aggregate (Figure 2) when the recycled concrete was exposed to a high temperature $\left(40^{\circ} \mathrm{C}\right)$ at the same $100 \%$ relative humidity at which it was cured. 


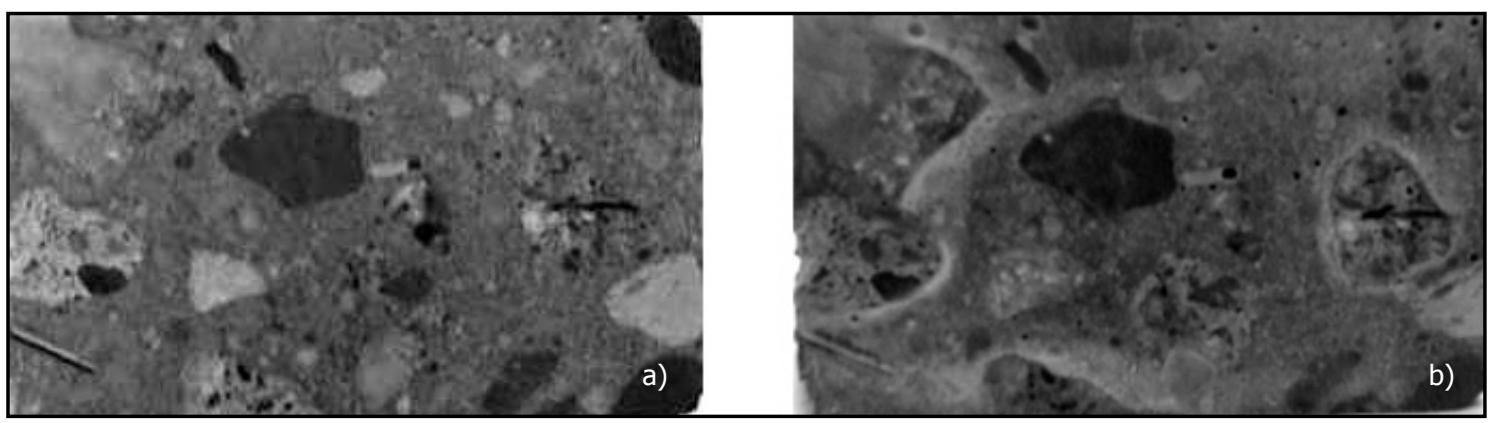

Figura 2. Imagen de las aureolas in la zona interfacial de los áridos reciclados del hormigón y la nueva pasta. (a) una pequeña muestra del hormigón saturado con presencia de aureolas (b) la muestra después de cuatro días a $40{ }^{\circ} \mathrm{C}$. Las muestras son de $45 \times 45 \mathrm{~mm}$.

Figure 2. Micrograph of halos at the interfacial transition zone between recycled concrete and new paste. (a) Small sample of saturated concrete without halos. (b) Same sample after four days at $40^{\circ} \mathrm{C} .45 \times 45-\mathrm{mm}$ samples.

\subsubsection{Preparación de muestras}

El hormigón de árido reciclado endurecido se mantuvo en la cámara húmeda durante 6 meses. Las muestras de hormigón de 45×35×20 mm y en condición de 100\% de humedad fueron colocadas en bolsas herméticas de plásticos e introducidas en un horno a $40{ }^{\circ} \mathrm{C}$. En estas condiciones el agua se transporta y aparecieron aureolas alrededor del mortero adherido del árido reciclado. Las aureolas aparecieron en la nueva ITZ del árido reciclado. La ITZ y las aureolas fueron analizadas mediante el microscopio óptico Leica Leitz DM-RXP y ESEM (Microscopio Electrónico de Barrido Ambiental) y sistema analítico EDX.

Para el análisis microscópico se prepararon láminas delgadas fluorescentes de $20 \mu \mathrm{m}$ de espesor. Las láminas delgadas fueron impregnadas, al vacio, con resina epoxi amarilla fluorescente. Las áreas del hormigón de baja densidad absorben la mayor cantidad de resina fluorescente $y$, consecuentemente, estas áreas son destacadas al analizar el hormigón a través del microscopio óptico. Esta metodología se describe con más detalle en Etxeberria et. al. (10).

El hormigón con árido reciclado, las aureolas y la determinación de la reactividad de la arena del mortero adherido del árido reciclado fueron analizados utilizando ESEM y análisis EDX.

\section{RESULTADOS Y DISCUSIÓN}

\subsection{Reactividad de los áridos reciclados}

Tal y como se ilustra en la Figura 3, los áridos gruesos reciclados y el mortero adherido sufren una expansión de $0,07 \%$ y $0,1 \%$ a 14 días, respectivamente. De acuerdo con la norma ASTM C1260, la arena original (presente en el mortero adherido) fue considerada potencialmente reactiva. En consecuencia, el ensayo se continuó hasta 28 días, en ese instante las barras de mortero lograban una expansión de 0,19\%. Este valor verifica el estado de áridos

\subsubsection{Sample preparation}

The hardened recycled concrete was kept in a humidity

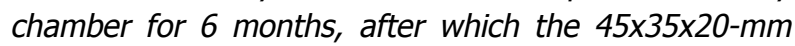
concrete samples were removed from the $100 \% \mathrm{RH}$ environment, wrapped in air-tight plastic bags and placed in a furnace at $40^{\circ} \mathrm{C}$. The halos appearing around the adhered mortar under these conditions and the ITZ on the recycled aggregate were analyzed under a Leica Leitz DM-RXP optical as well as under an environmental scanning electron microscope, and analyzed with EDX techniques.

Twenty- $\mu m$ thin sections of recycled concrete were prepared and vacuum-coated with yellow fluorescent epoxy resin for the microscopic analysis. The low intensity areas in the concrete absorb more fluorescent resin and are consequently more prominent in the optical microscope analysis. This methodology is described in greater detail in Etxeberria et al. (10).

The recycled concrete, halos and the sand in the mortar adhered to the recycled aggregate (to determine its reactivity) were analyzed under ESEM and with EDX techniques.

\section{RESULTS AND DISCUSSION}

\subsection{Recycled aggregate reactivity}

As Figure 3 shows, the recycled coarse aggregate and the mortar adhered to it expanded by $0.07 \%$ and $0.1 \%$, respectively, after the 14 days specified in the protocol. In light of those findings and further to standard ASTM C1260, the original sand (present in the adhered mortar) was suspected to be potentially reactive. Consequently, the trial was continued to the $28^{\text {th }}$ day, by which time the mortar specimens had expanded by $0.19 \%$. This value 
potencialmente reactivos. La expansión de los áridos finos continuó, y por ello el ensayo se mantuvo otros 28 días hasta un total de 56 días. En ese instante la pendiente expansión- edad disminuyó pero la expansión era alta, de 0,37\%, ver Figura 4.

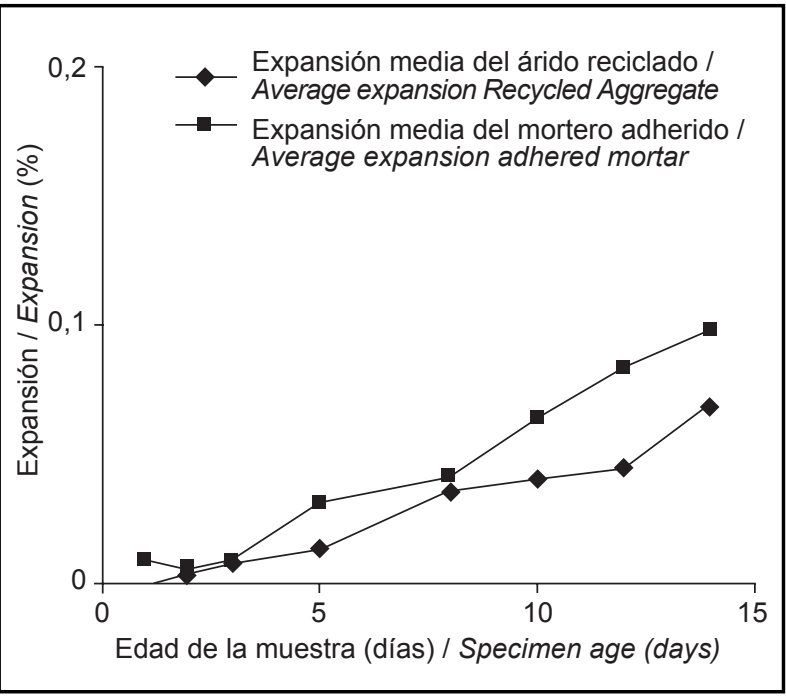

Figura 3. Expansión de los áridos reciclados y mortero adherido a 14 días, de acuerdo con ASTM C1260.

Figure 3. ASTM C1260 test: expansion of recycled aggregate and adhered mortar after 14 days.

\subsection{Propiedades del hormigón endurecido}

La Resistencia a compresión, a tracción indirecta y el módulo elástico del hormigón de árido reciclado a 28 días era de $38,2 \mathrm{MPa}, 2,8 \mathrm{MPa}$ y $28.635 \mathrm{MPa}$, respectivamente. Los valores obtenidos a 6 meses fueron 38,66 $\mathrm{MPa}, 3,28 \mathrm{MPa}$ y $28.080 \mathrm{MPa}$, respectivamente. Los ensayos se llevaron acabo de acuerdo a; UNE 83-30484: Resistencia a compresión, UNE 83-306-85: resistencia a tracción y UNE 83-316-1996: módulo de elasticidad.

\subsection{Análisis microscópico}

De acuerdo al análisis microscópico realizado mediante láminas delgadas fluorescentes, se determinó que el orden de amasado utilizado en la fabricación del hormigón fue fundamental para conseguir una zona de transición efectiva debido a la adherencia y acumulación del cemento en la superficie de los áridos reciclados, una relación agua/cemento baja, y consecuentemente un nueva efectiva zona de transición. En el hormigón convencional, la zona de transición, ITZ, usualmente es la parte más débil del hormigón debido a la acumulación del agua en este punto (11). Sin embargo, tal y como se puede apreciar en la Figura 5, en los áridos reciclados, debido a la acumulación del cemento, se produjo una buena interfase $y$, en este caso, el mortero adherido pasa a ser la parte más débil (12). confirmed the potential reactivity of the aggregate. Since the fine aggregate continued to expand, the trial was extended for yet another 28 days, for a total of 56. At that age, the slope of the expansion-age curve declined, but expansion was high, at $0.37 \%$ (see Figure 4).

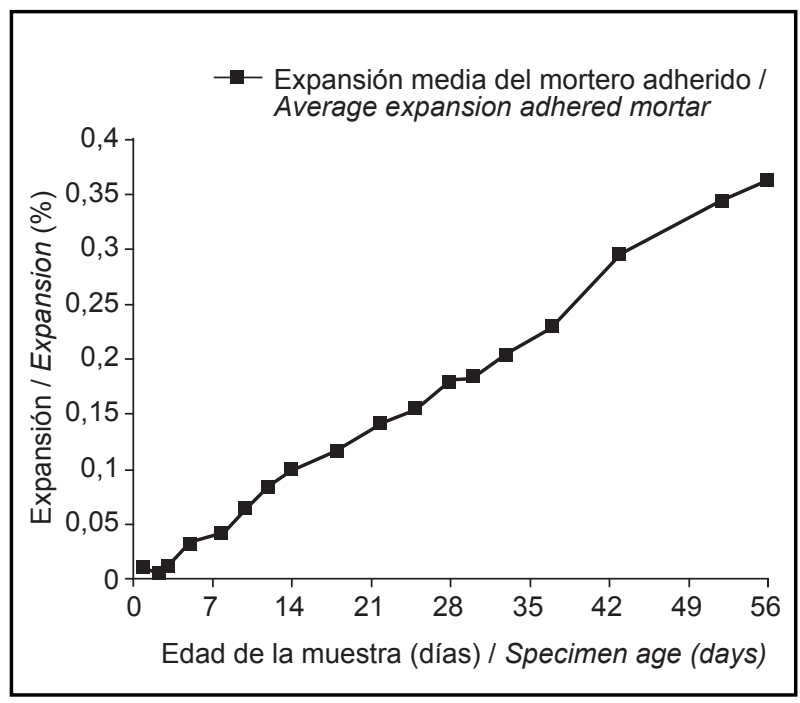

Figura 4. La expansión del mortero adherido a 56 días, de acuerdo con ASTM C1260.

Figure 1. ASTM C1260 test: expansion of adhered mortar after 56 days.

\subsection{Hardened concrete properties}

The compressive strength, splitting tensile strength and yield stress of the 28-day recycled concrete were 38.2 $\mathrm{MPa}, 2.8 \mathrm{MPa}$ and $28635 \mathrm{MPa}$, respectively. The 6-month values were $38.66 \mathrm{MPa}, 3.28 \mathrm{MPa}$ and $28080 \mathrm{MPa}$, respectively. The tests were conducted as specified in Spanish standards UNE 83-304-84 (compressive strength); UNE 83-306-85 (tensile strength) and UNE 83316-1996 (yield stress).

\subsection{Microscope analysis}

The microscope analysis of fluorescent thin sections revealed that the order in which the materials were mixed to manufacture the concrete was instrumental in obtaining an effective transition zone, to which the adherence and accumulation of cement on the surface of the recycled aggregate and the low water/cement ratio used also contributed. In conventional concrete, the interfacial transition zone, ITZ, is generally the weakest part of the material due to the water accumulating there (11). As Figure 5 shows, however, with the accumulation of cement on the recycled aggregate, a good interface was formed in which the adhered mortar was the weakest element (12). 


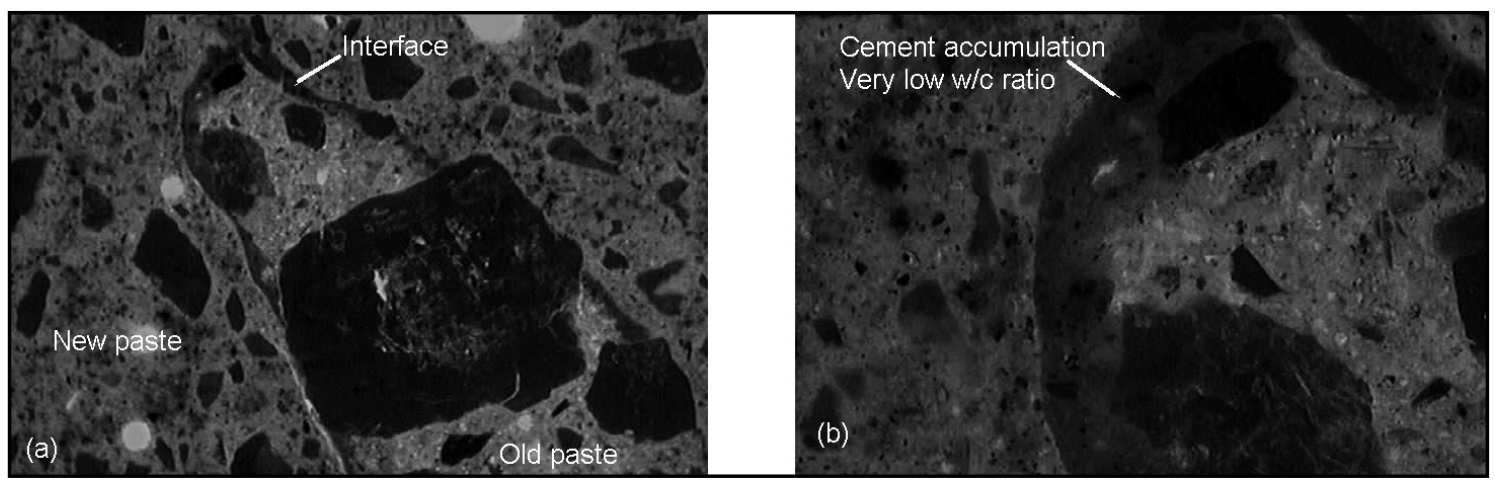

Figura 5. Láminas delgadas fluorescentes de hormigón de árido reciclado analizadas por microscopio óptico. Zona interfacial del árido reciclado. a) 3,95 mm ancho de campo, b) 1,03 mm ancho de campo (10).

Figure 5. Fluorescent thin section of recycled aggregate concrete examined under fluorescent light optical microscope. Recycled aggregate interface. a) Width of field: $3.95 \mathrm{~mm}, \mathrm{~b}$ ) width of field: $1.03 \mathrm{~mm}(10)$.

Las muestras sin pulir de hormigón fueron analizadas en el ESEM y la aureola (la línea densa) fue detectada en la ITZ, ver Figura 6. El análisis EDX (Figura 6-b) del área total de la Figura 6-a se define como CSH. La composición determinada era de esperar debido a que la aureola (la línea densa en ESEM) estaba sobre la pasta de cemento.
The unpolished concrete samples were analyzed under ESEM and the halo (bright line) was detected at the ITZ (see Figure 6). The EDX analysis (Figure 6-b) showed that the entire area in Figure 6-a comprised CSH. That composition was not surprising, for the halo (bright line on the ESEM micrograph) was located on the cement paste.
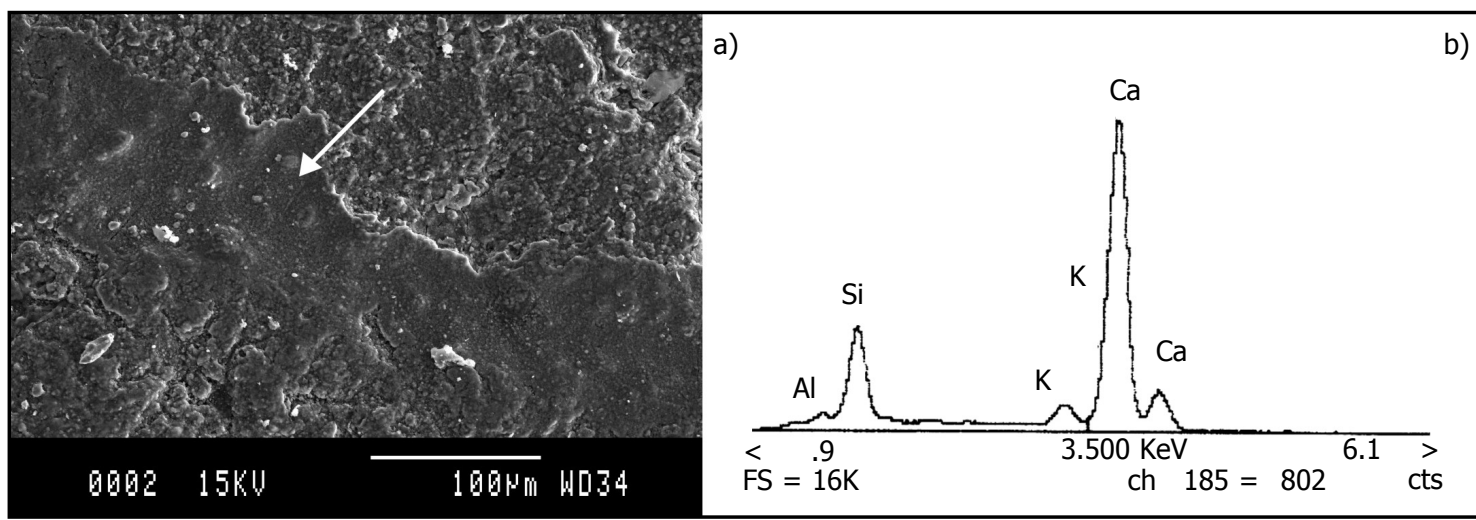

Figura 6. Zona interfacial entre el árido reciclado y la nueva pasta. a) Imagen ESEM, b) análisis de EDX.

Figure 6. Interfacial transition zone between recycled aggregates and new paste. a) ESEM imaging. b) EDX map analysis.

Tal y como se ve en la Figura 7, la concentración de sílice incrementa en la ITZ al ampliar el aumento (de $100 \mu \mathrm{m}$ a $10 \mu \mathrm{m})$. El análisis de las aureolas se realizó mediante diversos puntos sobre el material. El análisis reveló que la sílice era el principal componente de la aureola, ver Figura 8. Este análisis verifica que su composición se describe con Si-Ca-K y se identifica como la reacción álcali sílice. La Figura 9 ilustra una imagen general de la aureola, una imagen típica de Reacción álcali sílice.

De acuerdo con la Figura 8, la composición de la aureola estaba formado principalmente de $\mathrm{Si}, \mathrm{Ca}$, y K , con mayor cantidad de Si. Se analizó la aureola sin la pasta de cemento. El material de la aureola fue separado de la superficie de la pasta de cemento meticulosamente para evitar la inclusión de cualquier otro material antes de examinarlo por
As Figure 7 shows, the silica concentration in the ITZ grew with the magnification used (from $100 \mu \mathrm{m}$ to $10 \mu \mathrm{m}$ ). An analysis of the halos at several points in the material revealed that silica was the chief component (see Figure 8). Its composition was also observed to include $\mathrm{Ca}$ and $K$, confirming that it was the result of an alkali-silica reaction. The halo depicted in Figure 9 is an image typical of the alkalisilica reaction.

The halo was also analyzed without the cement paste by separating it from the surface of the paste with great care to exclude any possible foreign matter prior to examination under the ESEM. EDX analyses were conducted to determine the composition of the halos. Figure 10 shows the 
ESEM. Se realizaron algunos análisis EDX para determinar la composición de las aureolas. La Figura 10 ilustra la morfología y el análisis del mapa EDX del material de la aureola. morphology and EDX map of the constituent material.

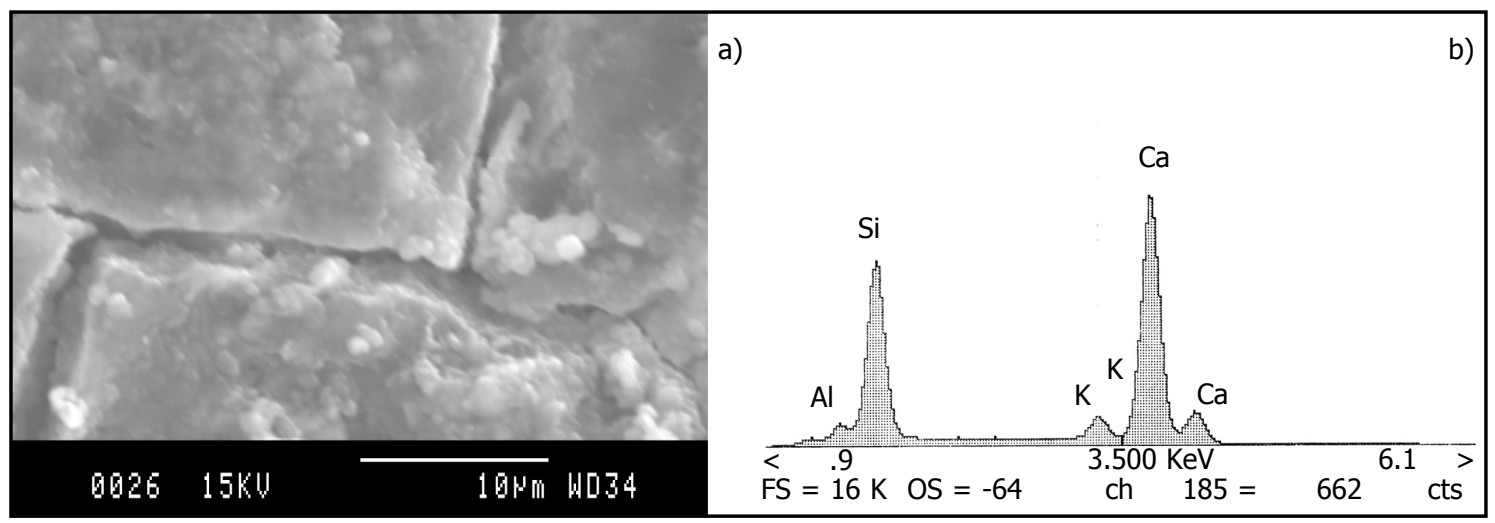

Figura 7. Reacción álcali sílice en la zona interfacial entre el árido reciclado y la nueva pasta. Análisis EDX del área total de la imagen. a) Imagen de ESEM, b) análisis EDX.

Figure 7. Hardened and shrunk ASR gel in interfacial transition zone between recycled aggregates and new paste. EDX map of the total area of the micrograph. A) ESEM imaging. b) EDX map.

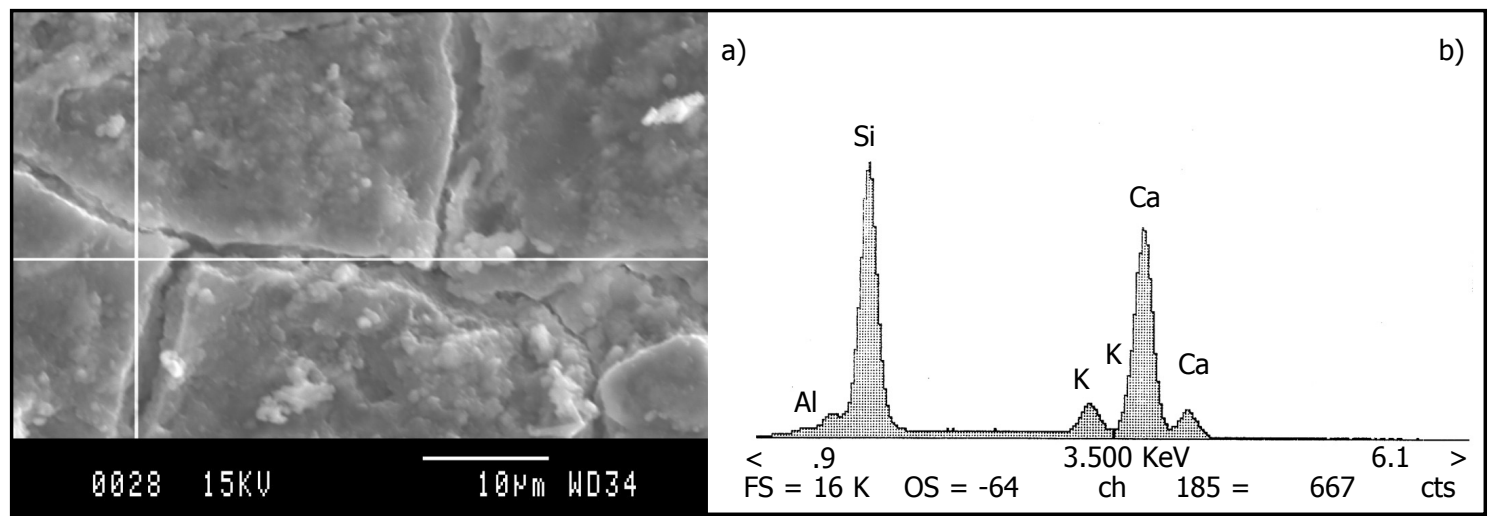

Figura 8. Análisis mediante puntos de la reacción álcali sílice en la zona interfacial entre el árido reciclado y la nueva pasta.

Figure 8. Spot analysis in hardened and shrunk ASR gel along interfacial transition zone between recycled aggregate and new paste.

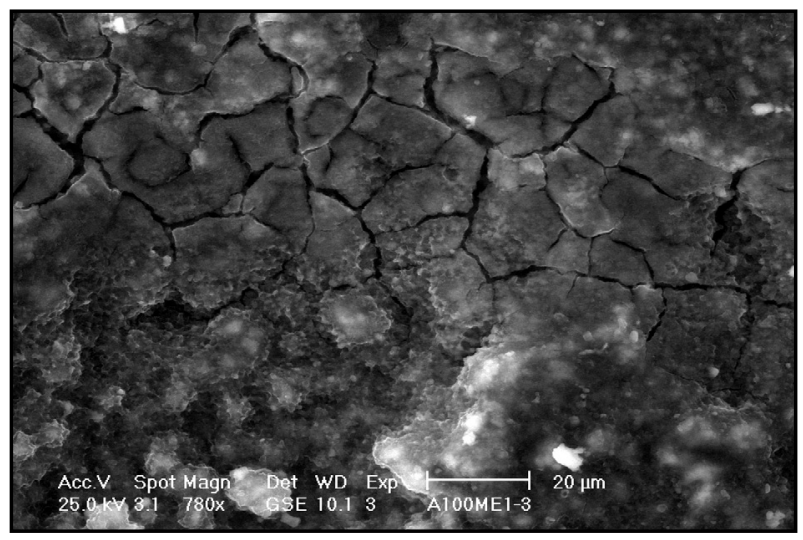

Figura 9. Imagen general del producto de reacción. Figure 9. Overview of the reaction product.

El análisis EDX fue definido mediante el análisis de numerosos puntos en el mismo material, todos los puntos se describían con la misma composición. La aureola fue examinada mediante difracción de rayos $X$ y se describió como materia amorfa.
The EDX analysis was conducted on numerous points on the same material, all of which were found to have the same composition. When analyzed with X-ray diffraction, the halo proved to be amorphous and more specifically to constitute an alkali-silica reaction (ASR) 


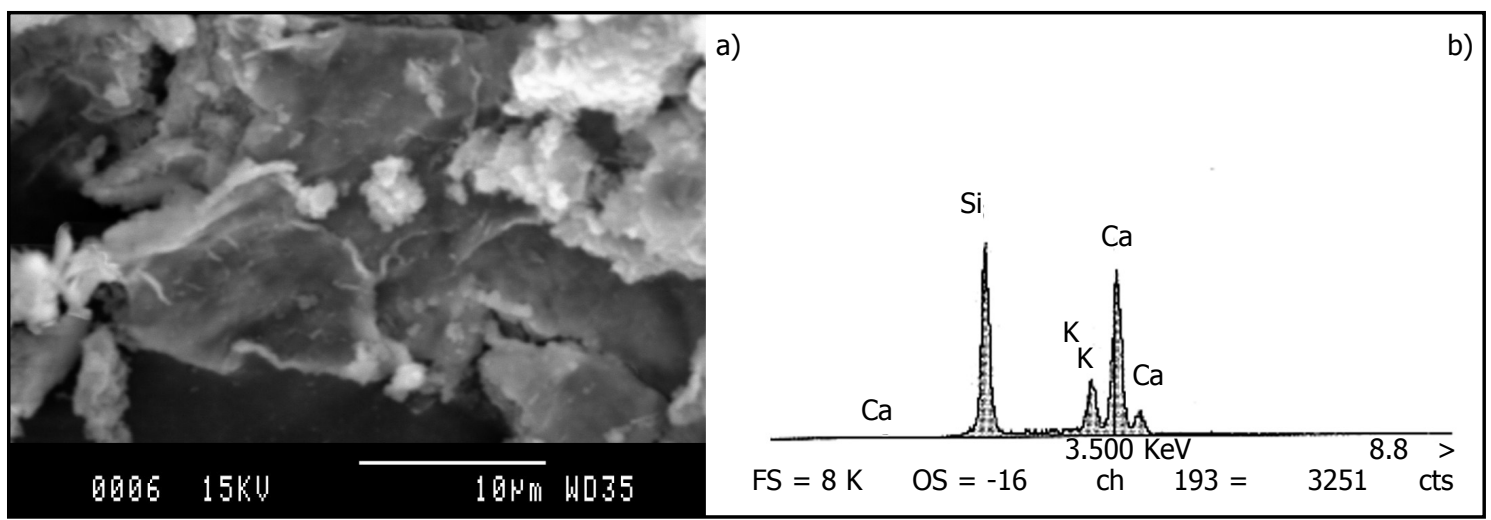

Figura 10. Análisis de la composición del producto de la reacción álcali sílice (aureola). a) imagen ESEM, b) análisis EDX. Figure 10. Halo (ASR gel) composition based on sampling from many points. A )ESEM imaging b) EDX map.

La aureola fue definida como gel Reacción Álcali Sílice (RAS). Debido a la acumulación de cemento en la superficie del árido, y a la capacidad de absorción del agua de los áridos reciclados los álcalis se acumularon en el mortero adherido. Tal y como se ha definido anteriormente, el árido fino original (presente en el mortero adherido) tenía la Si como componente principal. La solubilidad del $\mathrm{SiO}_{2}$ es fuertemente dependiente a las soluciones de $\mathrm{pH}$ altos. Con respecto a la sílice amorfa, su solubilidad es constante (a $10^{\wedge}-2,7 \mathrm{M}$ ) cuando la $\mathrm{pH}$ es inferior a 8 , mientras que incrementa rápidamente con respecto a mayores valores de $\mathrm{pH}$ (13). En este caso la alta cantidad de iones Hidroxilos $\left(\mathrm{OH}^{-}\right)$presentes en la solución pura, (debido a la alta concentración de álcalis, potasio y sodio), disuelve la sílice reactiva en la superficie del árido para formar gel álcali sílice.

Se fabricaron barras de mortero utilizando como arena el mortero adherido triturado y las barras se sometieron a solución de sodio un total de 56 días (ASTM C1260). Las barras de mortero se expandieron substancialmente debido a la reacción álcali sílice. Los áridos silicios se disolvieron, tal y como se puede ver en la Figura 11. gel. Due to the accumulation of cement on the aggregate surface and the water sorptivity of the recycled aggregate, the alkalis accumulated on the adhered mortar. As noted above, the chief component of the original fine aggregate (present in the adhered mortar) was Si. The solubility of $\mathrm{SiO}_{2}$ depends heavily on high $\mathrm{pH}$ values. The solubility of amorphous silica, in turn, is constant (a 10^-2.7 M) at $\mathrm{pH}$ values of under 8 , while it rises steeply with increasing $\mathrm{pH}$ at values higher than 8 (13). In this case the high proportion of hydroxyl ions $\left(\mathrm{OH}^{-}\right)$present in the pure solution (due to the high concentration of alkalis such as potassium and sodium) dissolved the reactive silica on the aggregate surface to form alkali-silica gel.

The adhered mortar was crushed and used as sand to prepare prismatic mortar specimens that were exposed to a sodium solution for a total of 56 days (ASTM C1260). The specimens expanded due to the alkali-silica reaction. The siliceous aggregate dissolved, as shown in Figure 11.

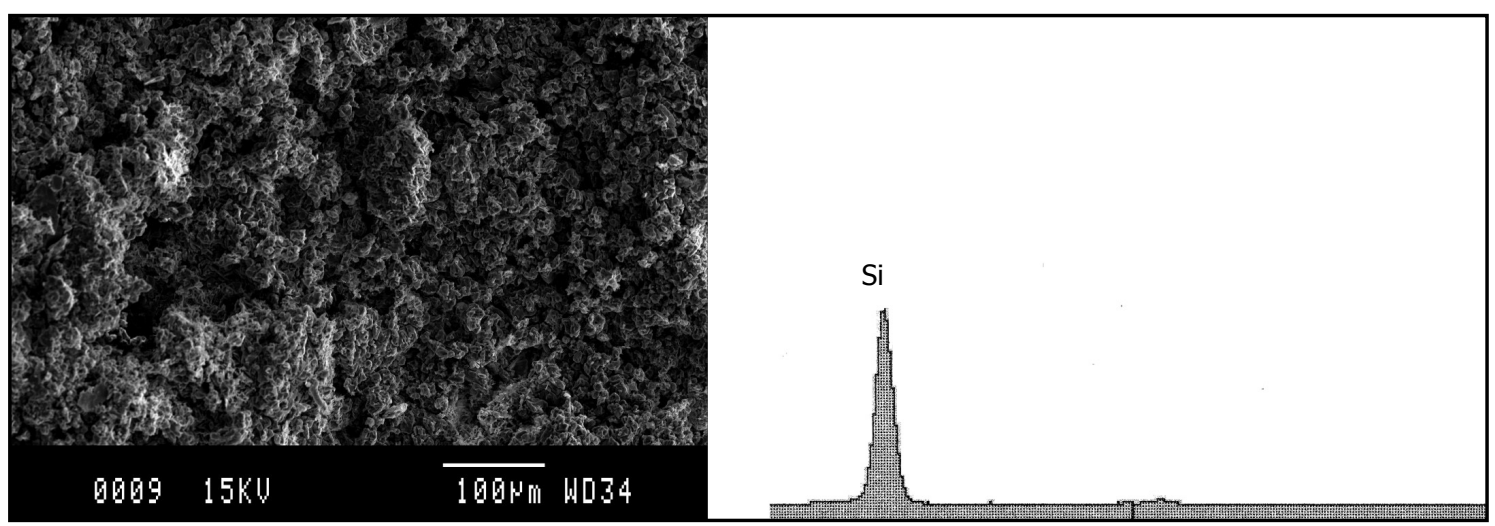

Figura 11. Árido silícico aparece totalmente disuelto en la solución álcali. Figure 11. Silica aggregate totally dissolved in alkali solution. 
La reacción álcali sílice aparece con diferentes morfologías, pero todas presentaban la misma composición de acuerdo con el análisis EDX, ver Figura 12.
The alkali-silica reaction adopted different morphologies, all of which had the same composition according to the EDX analysis (see Figure 12).

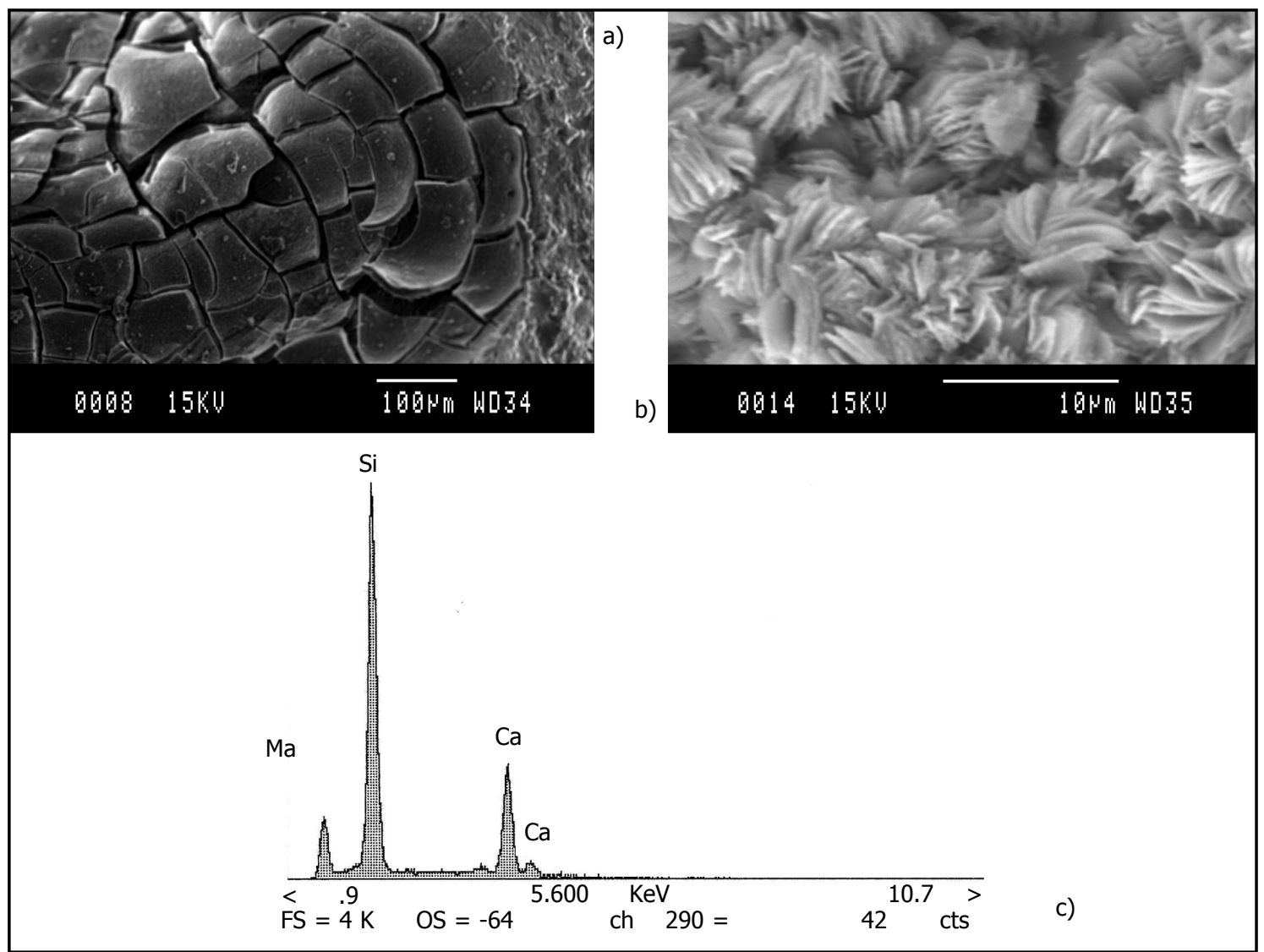

Figura 12. Diferente morfología de la reacción álcali sílice. La composición es Si-Ca-Na. a) imagen ESEM, b) imagen ESEM c) análisis EDX.

Figure 12. Alkali silica reaction morphologies. The composition is Si-Ca-Na. a)ESEM imaging, b) ESEM imaging, c) EDX map.

\section{CONCLUSIONES}

Basado en los resultados de esta investigación experimental, se han obtenido las siguientes conclusiones:

- Los áridos reciclados procedentes de demolición de estructuras de hormigón hay que tenerlos en consideración en el sentido de poder ser utilizados como áridos en hormigones, debido a la posibilidad de la presencia de arena silícea reactiva en su composición.

- La gel álcali sílice se produjo como resultado de:

1. La acumulación de cemento de alto contenido en álcalis en la zona de transición.

2. La presencia de árido fino reactivo en el mortero adherido.

3. La presencia de agua debido a la condición de saturación o casi saturación del hormigón.

- A los 6 meses de curado, la reacción álcali sílice fue localizada en la zona de transición. Las propiedades

\section{CONCLUSIONS}

The conclusions drawn from the above findings were as follows:

- Great care must be taken when using aggregate recycled from concrete demolition waste due to the possible presence of reactive siliceous sand in its composition.

- Alkali-silica gel was generated as a result of:

1. The accumulation of cement with a high alkali content in the transition zone.

2. The presence of reactive fine aggregate in the adhered mortar.

3. The presence of water in the soaked or nearly soaked concrete.

- The alkali-silica reaction was located in the transition zone in the 6-month concrete. The mechanical 
mecánicas del hormigón con árido reciclado eran similares a las obtenidas a los 28 días de curado.

- Para producir hormigones de alta durabilidad, en el caso de que los áridos originales fuesen reactivos o potencialmente reactivos se necesitaría utilizar cementos bajo en álcalis.

\section{AGRADECIMIENTOS}

Los autores quieren agradecer al programa de investigación medioambiental, "II Pla de Medi Ambient "Laboratori REAL" del Campus de Castelldefels" de la Universidad politécnica de Catalunya por su financiación a este trabajo de investigación. El primer autor quiere agradecer al Ing. M.H.J. van Maasakers del departamento de Civil Engineering Materials de la facultad de Ingeniería Civil de la Universidad Tecnológica de Delft por su colaboración en el análisis microscópico de las muestras. properties of this recycled concrete were found to be similar to the 28-day findings.

- When concrete is manufactured from recycled aggregate, if the aggregate in the initial material is reactive or potentially reactive, low-alkali cement must be used to ensure high durability.

\section{ACKNOWLEDGEMENTS}

The present research was funded by the Polytechnic University of Catalonia's "II Pla de Medi Ambient Laboratori REAL del Campus de Castelldefels". The senior author wishes to thank Engineer M.H.J van Maasakers of the Department of Civil Engineering, Materials at the Faculty of Civil Engineering, Delft University of Technology for the assistance provided in the microscopic analysis of the samples.

\section{BIBLIOGRAFÍA / BIBLIOGRAPHY}

(1) Desmyter, J. and Blockmans, S.: Evaluation of different measures to reduce the risk of alkali-silica reaction in recycled aggregate concrete. 11th International Conference on Alkali- Aggregate Reaction. Quebec (2000), pp. 603-612.

(2) Otsuki, N., et. al.: "Influence of Recycled Aggregate on Interfacial Transition Zone, Strength, Chloride Penetration and Carbonation of Concrete", Journal of Materials in Civil Engineering, volume 15 (September 2003). doi:10.1061/(ASCE)0899-1561(2003)15:5(443)

(3) Poon, C. S.; Shui, Z. H. lam L.; Fok, H. and Kou, S. C.: "Influence of moisture states of natural and recycled aggregates on the properties of fresh and hardened concrete". Cem. Concr. Res. 34 (2004) 31-36. doi:10.1016/S0008-8846(03)00186-8

(4) ASTM C1260: "Standard Test Method for Potential Alkali Silica Reactivity of Aggregates (Mortar-Bar Method)".

(5) UNE-EN 197-1:2000 Cement. Part 1: composition, specifications and criteria of common Cements. (Portland cement CEM I 52.5 R).

(6) Nealen, A.; Rühl, M.: "Consistency aspects in the production of concrete using aggregates from recycled demolition material" (1997) Berichtsband zu "Darmstadt Concrete97".

(7) Hansen, T. C.: "Recycled aggregate and recycled aggregate concrete". Second State-of-the-art Report developments 1945-1985. Materials and structures (RILEM), no 111 (1986).

(8) Etxeberria, M.; Vázquez, E.; Marí, A.; Barra, M.: "Influence of amount of recycled coarse aggregates and production process on properties of recycled aggregate concrete". Cem. Concr. Res. 37 (2007), 735-742. doi:10.1016/j.cemconres.2007.02.002

(9) EN 12350-2:2000. Testing fresh concrete. Slump test.

(10) Etxeberria, M.; Vázquez, E.; Marí, A. R.: "Microstructure analysis of hardened recycled aggregate concrete", Magazine of Concrete Research 58 (December 2006) 683-690. doi:10.1680/macr.2006.58.10.683

(11) Neville, A. M.: "Properties of Concrete", Longman 981-4053-56-2, 2000 by Pearson Education Asia.

(12) Salem, R. M.; Bordette, E. G.: "Role of chemical and mineral admixture on physical properties and frost-resistance of recycled aggregate concrete". ACI Materials Journal (September-October 1998) 558-563.

(13) Stumm, W. and Morgan, J. J.: "Aquatic Chemistry. An Introduction Emphasizing Chemical Equilibria in Natural Waters". Wiley. Chapters 7 and 8 (1970), 583 pp. 